\title{
Molecular Identification of Fungal Isolates from Textile Wastewater by ITS-RFLP Method
}

\author{
Ovidiu IORDACHE ${ }^{13^{*}}$, Calina Petruta CORNEA $^{1)}$, Camelia DIGUTA ${ }^{1}$, Steliana RODINO ${ }^{1)}$, Ioana IONESCU ${ }^{1)}$, \\ Adrian MATEI ${ }^{1)}$, Iuliana DUMITRESCU ${ }^{2)}$ \\ 1) Faculty of Biotechnology, University of Agronomical Sciences and Veterinary Medicine, 59 Marasti \\ Blvd., 011464, Bucharest, Romania \\ 2) Department of Materials Research \& Development, National R\&D Insitute for Textile \& Leather, 16 \\ Lucretiu Patrascanu Street, 030508, Bucharest, Romania \\ *Corresponding author, e-mail: iordacheovidiu.g@gmail.com
}

Bulletin UASVM Animal Science and Biotechnologies 72(2) / 2015

Print ISSN 1843-5262; Electronic ISSN 1843-536X

DOI:10.15835/buasvmcn-asb:11608

\begin{abstract}
Eight strains isolated from textile post-finishing wastewaters were subjected to molecular identification by ITS-RFLP (Internal Transcriber Spacer-Restriction Fragment Length Polymorphism) method, using ITS1 (5'-TCCGTAGGTGAACCTGCGG-3') and ITS4 (5'-TCCTCCGCTTATTGATATGC-3') DNA amplification primers for ITS region of the nuclear small-subunit rRNA gene. Restriction fragments analysis was conducted post PCR amplification, and cleaved with HaeIII, Hinfl, HhaI, MseI and SduI restriction enzymes. Differences in the lengths of the obtained amplicons were detected after gel electrophoresis, and restriction analyses of the PCR fragments led to identification of six out of eight isolates as belonging to fungi T. parceramosum/ T. reesei/ T. longi, Polyporus squamosus, Fusarium oxysporum and Trichoderma atroviride groups. The PCR ITS-RFLP molecular identification technique can be used successfully for routine screening of fungal isolates from various environments.
\end{abstract}

Keywords: fungi, ITS-RFLP, textile, wastewater.

\section{INTRODUCTION}

Textile industry generates large amounts of wastewater with high chemical content, such as acids and alkali, levelling agents, dispersant agents, dyes (Olikanni et al., 2006), which are discharged in public water effluents without prior treatment and have become a real environmental concern. Due to great microbial biodiversity, textile wastewaters have the potential of providing microbial strains that can be used successfully in bioremediation techniques. Fungal strains have shown great potential in treatment of textile wastewaters (Dayaram and Dasgupta, 2008; Andleeb et al., 2010), waste treatment and textile dye microbial degradation requiring suitable strains for extended bioremediation potential.

\section{AIMS AND OBJECTIVES}

The study aims to identify previously isolated fungal strains (Iordache and Cornea, 2014) from textile wastewaters that have the ability to degrade and decolorize textile dyes produced in the final effluents of textile dye processing. Microbial isolates from samples of textile industry wastewaters were preferred instead of collection strains, due to their already existent adaptive profiles to wastewater present agents.

\section{MATERIALS AND METHODS}

DNA extraction was performed according to the method of Raeder and Broda (Raeder and Broda, 1985), slightly modified (cell lysis was optimized by using glass beads and a MiniBeadbeater BioSpec), using DNA amplification for ITS region by ITS1 and ITS4 primers (White et al., 1990). Five restriction enzymes were used for PCR product restriction, with corresponding cleaving sites: HaeIII ( $5^{\prime} . . . G G^{\wedge} \mathrm{CC} . . .3^{\prime}$ and $\left.3^{\prime} . . . \mathrm{CC}^{\wedge} \mathrm{GG} . . .5^{\prime}\right)$, Hinfl (5'...G^ANTC....' and $3^{\prime}$ '...CTNA^G...5'), HhaI (5'...

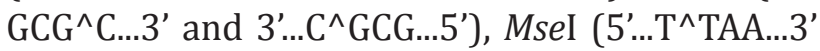




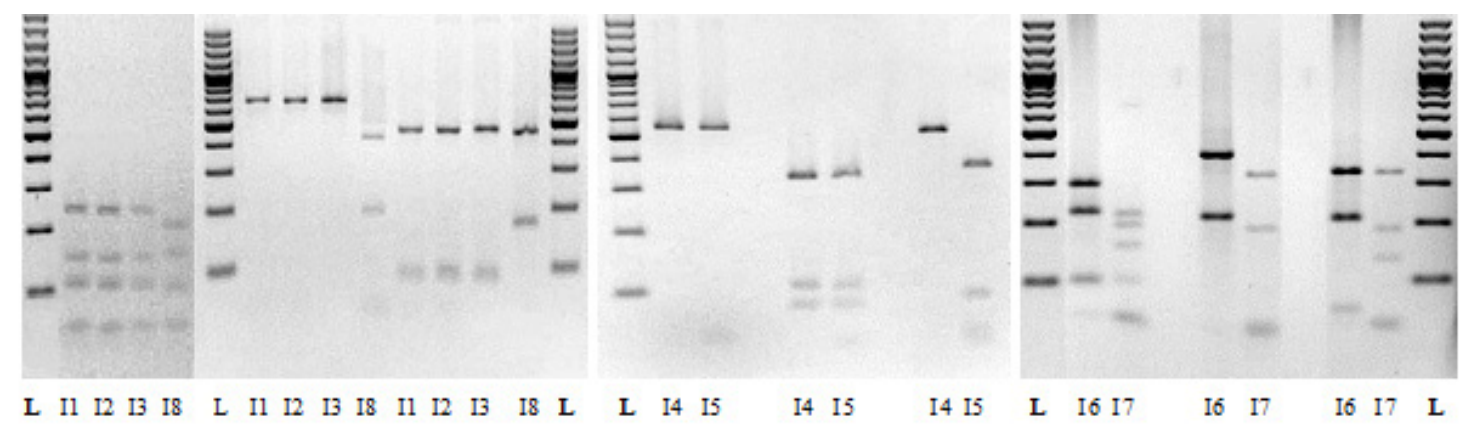

Fig. 1. Electrophoretic profiles of fragments obtained with restriction enzymes

Tab. 1. Restriction profiles for isolated fungal strains

\begin{tabular}{cccccc}
\hline \multirow{2}{*}{ Isolate } & \multicolumn{5}{c}{ Restriction fragments length (bp) } \\
\cline { 2 - 6 } & HaeIII & HinfI & HhaI & MseI & SduI \\
\hline T.parceramosum/T.reesei/T.longi & $70+90+480$ & - & $110+150+250$ & - & 630 \\
\hline T.parceramosum/T.reesei/T.longi & $70+90+480$ & - & $110+150+250$ & - & 630 \\
\hline T.parceramosum/T.reesei/T.longi & $70+90+480$ & - & $110+150+250$ & - & 630 \\
\hline Fusarium oxysporum & $90+110+340$ & - & - & 540 & 540 \\
\hline Polyporus squamosus & $90+110+340$ & - & - & $50+90+370$ & 540 \\
\hline Unidentified & $210+400$ & $80+210+340$ & $100+230+300$ & - & - \\
\hline Unidentified & $50+190+320$ & $70+140+190+340$ & $70+100+160+200+220$ & - & - \\
\hline Trichoderma atroviride & $170+450$ & - & $110+160+210$ & - & $190+430$ \\
\hline
\end{tabular}

and $\left.3^{\prime} . . . \mathrm{AAT}^{\wedge} \mathrm{T} . . .5^{\prime}\right)$ and $S d u \mathrm{I}\left(5^{\prime} . . . \mathrm{GdGCh}{ }^{\wedge} \mathrm{C} \ldots 3^{\prime}\right.$ and $\left.3^{\prime} . . . C^{\wedge} h C G d G \ldots 5^{\prime}\right)$. Differences in the lengths of the amplicons, post-PCR method, were detected after agarose gel electrophoresis, after staining with ethidium bromide and UV visualization.

\section{RESULTS AND DISCUSSION}

Eightfungalstrains weresubjected to molecular identification by ITS-RFLP method (White et al., 1990). Post analysis of electrophoretic profiles (Fig. 1) of the restrictions fragments allowed identification of fungal isolates, when compared to T.asperellum, T.hamatum, T.viride, Tatroviride, T.harzianum, T.reesei, T.longi, and T.parceramosum as belonging to T.parceramosum/T.reesei/T.longi (isolates I1-I3), Fusarium oxysporum (isolate 4), Polyporus squamosus (isolate I5) and Trichoderma atroviride (isolate I8) strains. Strains 6 and 7 were the only yeast strains isolated and their restriction profiles were compared to Sacharomyces cerevisiae, Yarrowia lipolytica, Metschnikowia pulcherima, Rhodotorula spp., which did not allow the identification of the species (Tab. 1).

\section{CONCLUSION}

In the present study, molecular techniques by ITS-RFLP analysis were successfully applied for the identification of some fungal isolates. Textile industry wastewater can develop a great diversity of bio-burden content, which can be used in reducing the residual concentration of textile dyes in post-finishing solutions.

Acknowledgement. This work was financed by Operational Program Human Resource Development 2007-2013, project POSDRU/159/1.5/S/ 132765 using European Social Fund.

\section{REFERENCES}

1. Andleeb S, Atiq N, Ali MI, Razi-UL-Hussain R, Shafique M, Ahmed B, Ghumro PB, Hussain M, Hameed A, Ahmed S. (2010). Biological treatment of textile effluent in stirred tank bioreactor. Int. J. Agric. Biol. 12 (2):256 - 260

2. Dayaram P, Dasgupta D. (2008) Decolorisation of synthetic dyes and textile wastewater using Polyporus rubidus. J. Environ. Biol. 29 (6): 831 - 836 
3. Iordache O, Cornea CP (2014). Bioburden Isolation of Various Microbial Strains from Textile Effluent, for Future Bio-Remediation Forming Consortia. Agriculture for Life, Life for Agriculture, June 5-7, 2014, Bucharest, Romania

4. Olukanni OD, Osuntoki AA, and Gbenle GO. (2006). Textile effluent biodegradation potentials of textile effluentadapted and non-adapted bacteria. Afri. J. Biotechnol. 5 (20):1980 - 1984
5. Raeder U, Broda P. (1985) Rapid preparation of DNA from filamentous fungi. Letters in Applied Microbiology 1:17-20.

6. White TJ, Bruns T, Lee S, Taylor J. (1990). Amplification and direct sequencing of fungal ribosomal RNA genes for phylogenetics: PCR protocols. A Guide to Methods and Applications, pp. 315-322. 